\title{
Interest rate sensitivities of externally and internally managed Australian REITs
}

\author{
J. Yong ${ }^{1}$ and A.K. Singh ${ }^{1}$ \\ ${ }^{1}$ Edith Cowan University, Western Australia \\ Email: jaime.yong@ecu.edu.au
}

\begin{abstract}
Real Estate Investment Trusts (REITs) in Australia experienced tremendous growth and investor interest following the crash of unlisted property funds in the 1990s. Since 2001, management structures have shifted from external property management to an internally advised model. The sector's returns had been notably rewarding up till the Global Financial Crisis but rising costs of debt and years of aggressive borrowing to fund expansions have eroded the values of REITs. Externally managed trusts had relatively higher levels of debt than their internally managed counterparts thus increasing the sensitivities to interest rate risks. Yet internally managed REITs engage in a wider set of operating activities which compound exposures to market and financial risks.

Using panel regressions, this paper aims to examine the joint impact of financial leverage and management structure on REIT returns in terms of their sensitivities towards stock market returns and changes to yields of 10-year bonds and 90-day bank accepted bills. We utilise a sample period of monthly data from January 1980 to March 2013. Panel quantile regressions are also employed to analyse how sensitivities to market risks, short and long-term interest rate risks vary at different parts of an economic cycle.

Our study finds that REITs are positively related to the stock market and the effect is greater for REITs with greater financial leverage as well as stapled trusts. REITs are only negatively affected by short-term interest rates at the lowest 5 per cent quantile of returns. Long-term interest rates have an inverse effect on REITs only at the upper 75 and 95 per cent quantiles. We consider the possibilities that rental yields and inflationary expectations may offset the influences of financing costs. Internal management appears to compound market and interest rate risks. These have implications on investors looking to select REITs as substitutes of direct property investments.
\end{abstract}

Keywords: $\quad$ REITs, financial leverage, interest rate risk, panel quantile regressions 


\section{INTRODUCTION}

For 20 years returns of the Real Estate Investment Trust (REIT) sector in Australia consistently outperformed general equities. However, during the Global Financial Crisis (GFC) the sector lost more than half its market value. The devaluations have been attributed to the high levels of borrowing incurred during the sector's boom phase from 2001 to 2007 . Previously perceived as liquid alternatives to direct real estate investment with benefits of relative lower levels of risk, REITs have enjoyed support from institutional investors. In 2006, 70 per cent of the sector's market value was held by investment funds, superannuation companies and self-managed pension funds. REITs were attractive because they paid high levels of dividends and the underlying properties owned could over time achieve capital growth.

The traditional corporate structure of a REIT involves a holding company which owns income producing real estate. Legislation dictates that at least 75 per cent of a REIT's value must be invested in real estate and 90 per cent of income to be distributed back to unit holders. Typically an external property manager will be hired to manage tenants, asset acquisitions and disposals, and negotiate debt contracts. However reliance on an external manager increases the likelihood of the agency problem to undermine a REIT's profitability and market performance (Sagalyn, 1996; Capozza and Seguin, 2000; Ambrose and Linneman, 2001). Between 2001 and 2005, many Australian REITs began adopting a stapled structure to internalise the asset management function. Each issued security comprised of units in the trust, which owns the underlying property assets and shares in the property management and development company, which pays dividends out of profits. Thus internally managed REITs should be able to secure lower costs of borrowing and have lower debt ratios.

The trust portion of a stapled REIT faces the same risks of an externally managed counterpart. Factors which drive real estate returns such as occupancy demand affect rental yields, and expectations on inflation will influence long-term cash flows and capital values. However, it is also expected that because internally managed REITs engage in property development they are considered riskier. From 2001 to 2007 REITs borrowed aggressively to fund expansions. Early in the decade, average gearing levels were approximately 15 to 20 per cent of total assets but a low interest rate environment and increased application of debt instruments saw an increase in gearing levels to 34 per cent in 2006 and 44 per cent in early 2007. Though debt laden REITs suffered the greatest losses from the GFC, since March 2009 most have since recovered due to balance sheet restructuring, reduction of debt, capital raisings and recovery of the general equity market.

\section{THEORETICAL BACKGROUND AND REVIEW OF RELATED LITERATURE}

Studies on the performance of REITs and the influence of factors such as interest rates, economic growth and inflation have applied indicators from the stock and bond markets. Findings in this area improves investors' understanding of what risk factors impact property investments and assist to increase the accuracy of forecasted returns.

Ibbotson and Seigel (1984) and Liow (2006) provide some theoretical reasoning to the linkages between property investments the general stock market and interest rates. During times of economic growth, increased corporate profits and share prices enable business expansions. With increased rental demand in the shortterm, the property market will experienced improved rental yields. Expectations of higher inflation improve long-term cash flows as well as capital values. However, rising rents and capital values could lead to higher interest rates and borrowing costs and this could then have a negative impact on real estate returns.

A notable study by Allen et al. (2000) examines U.S. REITs categorised according to asset structure, financial leverage, management structure and property-type specialisation against stock market and interest rate factors. They find REITs with higher levels of debt and especially those externally managed are more sensitive to market risk. In addition, all types of REITs are inversely related to short and long-term interest rates. The results of this paper raise the importance of comparing the differences between internally and externally managed Australian REITs. In particular, the stapled structure could reduce a REIT's sensitivity to interest rate risk through better negotiations of debt contracts by managers.

According to Swanson et al. (2002), the increased relevance of the stock market in pricing of REIT returns can be attributed to attention by institutional investors. The authors also contribute further evidence that the degree of financial leverage reduces returns when interest rates rise.

Using an international sample of sixteen countries including Australia, Hoesli and Serrano (2007) observe that correlations between REITs and the general stock market have been decreasing since the 1990s. 
Nonetheless, results from multi-factor regressions confirm positive relationships with stock and property market factors and negative relationships with bonds. The authors suggest that a large portion of return variation of REITs unexplained by stocks and interest rates could be captured if differences to management structure and degree of financial leverage are accounted for.

A study of U.K. property companies by Stevenson et al. (2007) find that returns are highly affected by changes to long-term bond yields instead of short-term bills even during periods of stable interest rates. They extend Liow's (2006) argument that rising interest rates not only increase borrowing costs, but can signal impending economic contraction and falling demand for rental space. This will further reduce values of properties owned by such companies.

Studies on Australian REITs which examine the impact of a stapled structure on returns have find increasing correlations with the stock market after 2003. Newell and Tan (2005) explain that because stapled trusts engage in property development, these REITs are more risky and result in higher returns. Ratcliffe and Dimowski (2007) also note that the defensive characteristics of REITs as a property investment against market risk have decreased. REITs have a significantly negative relationship with long-term interest rates but an insignificantly positive relationship with short-term rates. They suggest that REITs can reduce market and interest rate risk by maintaining lower debt ratios. During the GFC, Newell and Peng (2009) find gearing levels contribute to the underperformance of risk-adjusted returns. Externally managed trusts outperform internally managed counterparts because of lower debt levels and fewer holdings of international property assets.

Our paper aims to jointly examine the impact of borrowing and management structure in a sample period which includes the GFC and subsequent recovery of the REIT sector. The use of panel quantile regressions on REIT returns on stock market, short-term and long-term interest rate variables will allow us to determine if market and interest rate risks have consistent effects on returns at different ends of a business cycle.

\section{DATA AND METHODOLOGY}

The sample period of monthly data covers January 1980 to March 2013. Returns of REITs which are active, suspended and delisted are included in our study. Each REIT is categorised according to management structure: external/ traditional trust or internal/ stapled trust denoted as $T T$ and ST respectively. We further assign them into debt groups: high or low-to- medium denoted as $H D$ and $L D$. A REIT is classified as high debt if the proportion of debt is greater than 55 per cent. The debt ratio is defined as:

Debt Ratio $=\frac{\text { Total Debt }}{\text { Total Capital }} \times 100 \%$

REITs are included and removed from the groups $T T$ and $S T$ in the relevant month of listing, delisting, suspension, and changes to management structure. The same treatment is applied when sorting into debt groups. There are six groups in this study. ALLHD and ALLLD comprise of all REITs and consider the impact of borrowing regardless of management structure. TTHD and TTLD represent externally managed REITs while STHD and STLD comprise of internally managed ones, and these four groups consider the joint impact of management structure and level of borrowing.

Explanatory variables in this study comprise of monthly returns for the ASX100 stock market index (denoted as STOCK), along with changes in yields of 10-year government bonds and 90-day bank accepted bills $(B O N D$ and $B I L L)$ to represent market and interest rate risks. We expect bonds to proxy for long-term borrowing costs but can also reflect inflationary expectations. Bills represent short-term costs of debt and these may also be indicative of rental yields. A dummy variable to denote the Global Financial Crisis $(G F C)$ takes on the value of 1 for the months from September 2007 to August 2009 and zero otherwise.

We first use a linear panel data model to analyse the effect of explanatory variables in the whole dataset. The basic linear panel model can be represented as follows;

$y_{i t}=\alpha+x_{i t}^{\prime} \beta+c_{i}+u_{i t}$

Here $y_{i t}$ represents the dependent variable of REIT returns across $i$ entities for time $t . x^{\prime}$ are the explanatory variables STOCK, BOND and BILL minus the constant. $\alpha$ is the intercept, $\beta$ a vector of parameters, $c_{i}$ captures the individual specific effect and $u_{i t}$ is the error term.

Panel analysis has two basic models; fixed effect model and the random effect model. The individual specific effect in the fixed effects model is correlated with the explanatory variables (independent variables) whereas in the random effects model this individual specific effect is uncorrelated with the explanatory 
variable. The details of the linear panel data models are well documented in various textbook and hence we will not discuss them in detail. See Baltagi (2001), Woolridge (2002) among others for further comprehensive details.

The analysis is then carried out using quantile regressions for panel data at the 5, 25, 50, 75, and 95 per cent quantiles of interest, ranging from lower to higher quantiles. These quantiles cover the extreme lower to extreme higher tails of the distribution and hence provide a more comprehensive picture of the relationships.

The simple Ordinary Least Squares (OLS) regression method assumes a multivariate normal distribution between the dependent and the explanatory variable which focusses on the mean of the distribution. The assumption of normality makes the computation easy but is not useful when the variables have skewed distributions, and where linear regression is incapable of describing the conditional distribution of the dependent variable. Quantile regression as introduced by Koenker and Basset (1978), as an extension of OLS. It allows the relationships between dependent and independent variables to be quantified across different quantiles of the conditional distribution of the dependent variable. Quantile regression has advantages over OLS, as it is robust against outliers and it avoids the assumption that the error terms are independent and identically distributed.

The estimation process starts with the central median case in which the median regressor estimator minimizes a sum of absolute errors, as opposed to OLS which minimizes the sum of squared errors. The estimation of other regression quantiles is achieved by minimizing an asymmetrically weighted sum of absolute errors. Together, the ensemble of estimated conditional quantile functions offer a much more comprehensive view of the effect of covariates on the location, scale and shape of the distribution of the response variable.

The quantile regression model as presented in Alexander (2008) follows;

$Y=\alpha_{q}+\beta_{q} X+e$

$\alpha_{q}$ and $\beta_{q}$ for $q^{\text {th }}$ quantile are estimated by solving the following optimization problem.

$\min _{\alpha, \beta} \sum_{t=1}^{T}\left(q-1_{Y_{t} \leq \alpha+\beta X_{t}}\right)\left(Y_{t}-\left(\alpha+\beta X_{t}\right)\right)$,

where

$1_{Y_{t} \leq \alpha+\beta X_{t}}=\left\{\begin{array}{lr}1 & \text { if } Y_{t} \leq \alpha+\beta X_{t} \\ 0 & \text { Otherwise }\end{array}\right.$

When running quantile regression on a panel data structure where the entities are observed over time, equation (3) can be rewritten as:

$Y_{i t}=\beta_{q} X_{i t}^{\prime}+e_{i t}$

where $i=1, \ldots, N$ and $t=1, \ldots, T$ observations.

Panel quantile regression with fixed and random effects is a fairly new technique, with the estimation process to include fixed or random effects in a model being different to a simple linear quantile regression. There has been little, but growing interest in these estimation methods (Koenker, 2004; Lamarche, 2010; Canay, 2011; Galvao, 2011).

According to the descriptive statistics in Table 1 REIT returns do not follow a normal distribution and so it is important to investigate the effect of independent variables across quartiles using panel quantile regressions. In this study we use the penalized quantile regression approach for panel data proposed by Koenker (2004) to evaluate the relationship of REITS returns with STOCK, BOND and BILL in a fixed effects panel data model.

We expect REITs to be positively related to the general stock market because they are exchange-traded. However due to their underlying holdings in real estate, they are also expected to be largely influenced by property market factors. We expect to find a negative relationship with interest rate changes caused by the impact of borrowing costs, but the effects of changes in demand for rental space and inflationary expectations could result in positive associations instead.

\section{RESULTS}

Table 1 reports the descriptive statistics of variables employed. Panel regressions of REITs with low debt contain more observations than those with high debt. REITs with higher levels of borrowing had negative average monthly returns and higher standard deviation of returns compared to counterparts with lower debt 
ratios. While returns of externally managed REITs were negatively skewed, internally managed REITs showed positive skewness. REIT returns were more volatile than stock market returns and changes to interest rates. According to the results of skewness and excess kurtosis the dependent and independent variables all do not conform to a normal distribution.

Table 1:Descriptive Statistics

\begin{tabular}{|c|c|c|c|c|c|c|c|c|c|}
\hline \multirow{4}{*}{$\begin{array}{l}\mathrm{N} \text { obs. } \\
\text { Min. }\end{array}$} & \multicolumn{6}{|c|}{ Dependent Variables } & \multicolumn{3}{|c|}{ Explanatory Variables } \\
\hline & $A L L L D$ & $T T L D$ & $S T L D$ & $A L L H D$ & TTHD & $S T H D$ & STOCK & $B O N D$ & $B I L L$ \\
\hline & 7669 & 5083 & 2528 & 1943 & 1263 & 685 & 399 & 399 & 399 \\
\hline & -2.6598 & -2.6598 & -1.0116 & -1.8255 & -1.3876 & -1.8255 & -0.4979 & -0.0130 & -0.0463 \\
\hline Max. & 2.3336 & 2.3336 & 1.8739 & 3.6209 & 1.3148 & 3.6209 & 0.2074 & 0.0160 & 0.0573 \\
\hline Median & 0.0040 & 0.0003 & 0.0080 & 0.0000 & 0.0000 & 0.0000 & 0.0101 & -0.0002 & -0.0001 \\
\hline Mean & 0.0071 & 0.0071 & 0.0071 & -0.0196 & -0.0188 & -0.0203 & 0.0065 & -0.0002 & -0.0002 \\
\hline Stdev. & 0.1415 & 0.1490 & 0.1268 & 0.2361 & 0.2058 & 0.2832 & 0.0542 & 0.0037 & 0.0078 \\
\hline Skew. & 0.1723 & -0.4502 & 2.1902 & 1.8506 & -0.6734 & 3.5236 & -2.1658 & 0.3775 & 0.2860 \\
\hline Kurt. & 63.6427 & 67.0083 & 42.6587 & 44.9635 & 11.0032 & 55.6656 & 21.9602 & 4.8542 & 17.2440 \\
\hline
\end{tabular}

Notes: The dependent variables comprise of REITs sorted into groups based on management structure and debt ratios. Number of observations for STOCK, BOND and BILL are based on the entire sample period January 1979 to March 2013 and will match those of the dependent variables when regressions are conducted.

Table 2: Panel regressions

\begin{tabular}{|c|c|c|c|c|}
\hline Dependent Variable & STOCK & $B O N D$ & $B I L L$ & $G F C$ \\
\hline$A L L L D$ & $0.7643^{* * *}$ & -0.8036 & $1.5908^{* * *}$ & $-0.0346^{* * *}$ \\
\hline TTLD & $0.6352^{* * *}$ & -0.6386 & $1.3071^{* *}$ & $-0.0365^{* * *}$ \\
\hline$S T L D$ & $1.0620^{* * *}$ & $-2.6579^{* * *}$ & $2.2086^{* * *}$ & $-0.0347^{* * *}$ \\
\hline ALLHD & $1.4399^{* * *}$ & -2.8545 & $5.1387^{* *}$ & $-0.0668^{* * *}$ \\
\hline$T T H D$ & $1.2338^{* * *}$ & 0.4288 & 1.5832 & $-0.0936^{* * *}$ \\
\hline$S T H D$ & $1.8018^{* * *}$ & $-9.0019^{*}$ & $-11.7377^{* * *}$ & -0.0247 \\
\hline
\end{tabular}

Notes: Results are based on estimations of Equation $2 .^{*},{ }^{* *}$ and ${ }^{* * *}$ denote statistically significant coefficients at the 10,5 and 1 per cent levels respectively.

Results of the panel regressions in Table 2 show that sensitivities of REITs to market risk increases with higher debt ratios. Market risk impact internally managed REITs to a greater extent than externally managed ones. The impact of changes in long-term interest rates is only evident for internally managed trusts. REITs with lower levels of borrowing benefit from higher rental yields associated with positive changes to shortterm interest rates, and the effect is stronger for those managed internally. However, this benefit is eliminated with increased debt and the sensitivity to interest rate risk is compounded for REITs that engage in a wider set of operating activities.

Coefficients in panel quantile regressions of Table 3 show that sensitivities to interest rate changes vary in upward and downward market conditions. At the very worst of times (lowest 5 per cent quantile), REITs are generally not influenced by the stock market. Despite decreasing interest rates during business cycle downturns, negative coefficients with the short-term interest rate risk factor provide evidence that lower rental yields underpin property investment returns. The relationship between long-term interest rates is positive for high-debt REITs, more so for those managed internally. So when 10-year bond yields decrease, expectations of lower inflation levels would mean constrained capital growth in property values and decreased rental income.

The impact of subdued rental yields versus modestly decreasing rates of 90-day bank start to negate each other at the lower 25 per cent quantile. Returns of externally managed REITs with low debt start to increase as costs of borrowing remain relatively cheaper but the lack of a significant coefficient for internally managed counterparts show the effect of rental yields outweigh the easing of borrowing costs. REITs with high debt show no sensitivities to short-term interest rates, again likely due to the opposing effect of these two effects. It is also worthwhile to note that sensitivities to the stock market risk are significant and positive for REITs from this quartile and moving upwards along the return distribution.

At the median quartile, low-debt REITs are inversely related to changes in long-term interest rates. The descriptive statistics show that changes to interest rates are negative and this could mean that lower borrowing costs and low inflationary expectations boost REIT returns. The effect of interest rate risk on highdebt REITs is not clearly evident at this point of the distribution. In comparison, REITs display a significantly negative relationship with 10 -year bond yields at the upper 75 per cent quantile. The effect is stronger for internally managed REITs and with higher levels of debt. So when economic conditions start to improve not even expectations of increased rental income outpace increased financing costs. 
Yong and Singh, Interest rate sensitivities of externally and internally managed Australian REITs

Table 3: Panel quantile regressions

\begin{tabular}{|c|c|c|c|c|}
\hline Dependent Variable & STOCK & $B O N D$ & $B I L L$ & $G F C$ \\
\hline $\begin{array}{l}\text { Tau }=\mathbf{0 . 0 5} \\
A L L L D \\
T T L D \\
S T L D\end{array}$ & $\begin{array}{l}0.0588 \\
0.0180 \\
0.1713^{* * *}\end{array}$ & $\begin{array}{l}0.2455 \\
-0.0496 \\
1.3753\end{array}$ & $\begin{array}{l}-1.0734^{* * *} \\
-0.7381^{* *} \\
-2.2340^{* *}\end{array}$ & $\begin{array}{l}-0.3952^{* * *} \\
-0.3997 \\
-0.3748^{* * *}\end{array}$ \\
\hline $\begin{array}{l}\text { ALLHD } \\
T T H D \\
\text { STHD }\end{array}$ & $\begin{array}{l}0.0575 \\
0.0815 \\
-0.1282\end{array}$ & $\begin{array}{l}7.6305^{* * *} \\
5.3542^{* *} \\
13.0701^{* * *}\end{array}$ & $\begin{array}{l}-7.0013^{* * *} \\
-5.4891^{*} \\
-8.4999^{* *}\end{array}$ & $\begin{array}{l}-0.6011^{* * *} \\
-0.5844^{* * *} \\
-0.6358^{* * *}\end{array}$ \\
\hline $\begin{array}{l}\text { Tau }=\mathbf{0 . 2 5} \\
A L L L D \\
T T L D \\
S T L D \\
A L L H D \\
T T H D \\
\text { STHD }\end{array}$ & $\begin{array}{l}0.2728^{* * *} \\
0.1875^{* * *} \\
0.4906^{* * *} \\
0.5384^{* * *} \\
0.4580^{* * *} \\
0.8568^{* * *}\end{array}$ & $\begin{array}{l}-0.1013 \\
-0.2918 \\
-0.3685 \\
\\
3.0902^{*} \\
2.7833 \\
3.3127\end{array}$ & $\begin{array}{l}-0.6052^{* * *} \\
-0.4958^{* *} \\
-0.6290 \\
2.7218 \\
2.8136 \\
3.0955\end{array}$ & $\begin{array}{l}-0.1202^{* * *} \\
-0.1148^{* * *} \\
-0.1260^{* * *} \\
-0.1752^{* * *} \\
-0.1651^{* * *} \\
-0.1855^{* * *}\end{array}$ \\
\hline $\begin{array}{l}\text { Tau }=\mathbf{0 . 5 0} \\
A L L L D \\
T T L D \\
\text { STLD } \\
\\
\text { ALLHD } \\
\text { TTHD } \\
\text { STHD }\end{array}$ & $\begin{array}{l}0.4443^{* * *} \\
0.3559^{* * *} \\
0.6720^{* * *} \\
0.8163^{* * *} \\
0.7271^{* * *} \\
1.0567^{* * *}\end{array}$ & $\begin{array}{l}-1.0105^{* * *} \\
-1.0135^{* * *} \\
-1.7265^{* * *} \\
-1.5574^{*} \\
-1.1910 \\
-2.9562\end{array}$ & $\begin{array}{l}-0.2120 \\
-0.0519 \\
-0.4424 \\
\\
2.7653 \\
3.4171^{*} \\
3.3225\end{array}$ & $\begin{array}{l}-0.0236^{* * *} \\
-0.0232^{* * *} \\
-0.0241^{* * *} \\
-0.0446^{* * *} \\
-0.0389^{* * *} \\
-0.0507^{* * *}\end{array}$ \\
\hline $\begin{array}{l}\text { Tau }=\mathbf{0 . 7 5} \\
A L L L D \\
T T L D \\
\text { STLD } \\
\text { ALLHD } \\
T T H D \\
\text { STHD }\end{array}$ & $\begin{array}{l}0.5664^{* * *} \\
0.4928^{* * *} \\
0.8365^{* * *} \\
0.8762^{* * *} \\
0.8094^{* * *} \\
1.1418^{* * *}\end{array}$ & $\begin{array}{l}-1.8735^{* * *} \\
-1.6481^{* * *} \\
-3.3604^{* * *} \\
-3.7980^{* * *} \\
-3.5015^{* * *} \\
-5.7326^{* * *}\end{array}$ & $\begin{array}{l}0.1282 \\
-0.0255 \\
0.0830 \\
\\
1.5361 \\
0.3733 \\
4.7408\end{array}$ & $\begin{array}{l}0.0396^{* * *} \\
0.0492^{* * *} \\
0.0390^{* * *} \\
0.0439^{* * *} \\
0.0376^{* * *} \\
0.0613^{* *}\end{array}$ \\
\hline $\begin{array}{l}\text { Tau }=\mathbf{0 . 9 5} \\
A L L L D \\
T T L D \\
S T L D\end{array}$ & $\begin{array}{l}0.7068^{* * *} \\
0.5781^{* * *} \\
1.0023^{* * *}\end{array}$ & $\begin{array}{l}-2.6039^{* * *} \\
-2.1169^{* * *} \\
-4.6889^{* *}\end{array}$ & $\begin{array}{l}0.3617 \\
0.2265 \\
1.1637\end{array}$ & $\begin{array}{l}0.2771^{* * *} \\
0.2890^{* * *} \\
0.2611^{* * *}\end{array}$ \\
\hline $\begin{array}{l}\text { ALLHD } \\
T T H D \\
\text { STHD }\end{array}$ & $\begin{array}{l}1.1468^{* * *} \\
0.9564^{* * *} \\
1.5795^{* * *}\end{array}$ & $\begin{array}{l}-8.9530^{* * *} \\
-6.6906^{* * *} \\
-14.4624^{* * *}\end{array}$ & $\begin{array}{l}8.4443^{* * *} \\
4.3999 \\
16.4890^{* *}\end{array}$ & $\begin{array}{l}0.3414^{* * *} \\
0.2673^{* * *} \\
0.4252^{* * *}\end{array}$ \\
\hline
\end{tabular}

Notes: Results are based on estimations of Equation $6 .^{*},{ }^{* *}$ and ${ }^{* * *}$ denote statistically significant coefficients at the 10,5 and 1 per cent levels respectively.

The upper 95 per cent quantile represents the very best of market conditions. At this point, the results again show the importance of long-term interest rate risk underpinning REIT returns. Internally managed REITs with high levels of debt greatly benefit from robust rental yields, as the coefficient with short-term rates is significantly positive and large.

Our results concur with much of the earlier studies mentioned. In particular, we find similarities with Stevenson et al. (2007), Newell and Tan (2005) and, Ratcliffe and Dimowski (2007). However, in contrast to Newell and Peng (2009), the debt ratios of externally managed REITs were higher than stapled ones. This study also finds the negative impact of interest rate risk only affects REITs during stable and expanding market conditions.

\section{CONCLUSION}

This study examines how the degree of financial leverage and choice of internal or external REIT management influence the sensitivities to market and interest rate risks. We use a sample period which includes the emergence of the sector, its boom phase, subsequent downturn due to the GFC and recovery. Four findings are evident in our research. First, the effect of stock market risk increases with higher debt ratios, and has a greater impact on internally managed REITs. Second, sensitivities to interest rates vary 
during upward and downward market conditions. At the very worst of times, poor rental yields and low levels of inflation reduce cash flow and capital growth for all REIT types. Thirdly, the impact of long-term financing costs undermining REIT returns is evident only during robust market conditions. As expected, REITs with higher debt levels are more affected than those which borrow less. Lastly, though internally managed REITs that borrow more are also more sensitive to interest rate risks, the increased spread of operating activities promise good returns when rental yields are high.

There are some implications to these findings. Portfolio managers looking to reduce exposures to interest rate risks inherent in property investments should choose externally managed REITs with low levels of debt. Internally managed REITs with high levels of debt have compounded benefits during extremely favourable market conditions, but also expose investors to extreme losses during market reversals. Investors looking to replicate direct real estate investments in their portfolios should select externally managed REITs or stapled ones with less borrowing.

\section{REFERENCES}

Alexander, C. (2008). Market risk analysis: Practical financial econometrics. Vol. II. Wiley publishing.

Ambrose, B.W. and Linneman, P. (2001), REIT organisational structure and operating characteristics. Journal of Real Estate Research, 21(3), 141 - 161.

Baltagi, B. (2001), Econometric analysis of panel data. 3rd edition. John Wiley and Sons Ltd.

Canay, I. A. (2011), A simple approach to quantile regression for panel data. The Econometrics Journal, $14(3), 368-386$.

Capozza, D.R. and Seguin, P.J. (2000), Debt, agency, and management contracts in REITs: The external advisor puzzle. Journal of Real Estate Finance and Economics, 20(2), 91 - 116.

Galvao, A.F. (2011), Quantile regression for dynamic panel data with fixed effects. Journal of Econometrics, $164(1), 142-157$.

Hoesli, M., and Serrano, C. (2007), Securitised real estate and its link with financial assets and real estate: An international analysis. Journal of Real Estate Literature, 15(1), 59 - 84.

Ibbotson, R.G. and Seigel, L.B. (1984), Real estate returns: A comparison with other investments. AREUEA Journal, 12(3), $219-242$.

Koenker, R. (2004), Quantile regression for longitudinal data. Journal of Multivariate Analysis, 91, 74-89.

Koenker, R. and Bassett, G. Jr. (1978), Regression quantiles. Econometrica, 46(1), 33-50.

Lamarche, C. (2010), Robust penalised quantile regression estimation for panel data. Journal of Econometrics, 157(2), 396 - 408.

Liow, K.H. (2006), Dynamic relationship between stock and property markets. Applied Financial Economics, $16(5), 371-376$.

Newell, G., and Peng, H.W. (2009), The Impact of the Global Financial Crisis on A-REITs. Pacific Rim Property Research Journal, 15(4), 453 - 470.

Newell, G., and Tan, Y.K. (2005), The changing risk profile of listed property trusts. Paper presented at The Pacific Rim Real Estate Society Conference, Melbourne, 23 - 27 January 2005.

Ratcliffe, C., and Dimovski, W. (2007), The responsiveness of LPT returns and their attributes. Pacific Rim Property Research Journal, 13(3), 208 - 297.

Sagalyn, L.B. (1996), Conflicts of interest in the structure of REITs. Real Estate Finance, 13(2), 34 - 51.

Stevenson, S., Wilson, P.J. and Zurbruegg, R. (2007), Assessing the time-varying interest rate sensitivity of real estate securities. The European Journal of Finance, 13(8), 705 - 715.

Swanson, Z., Theis, J. and Casey, M.K. (2002), REIT risk premium sensitivity and interest rates. Journal of Real Estate Finance and Economics, 24(3), 319 - 330.

Wooldridge, J. (2002), Econometric analysis of cross-section and panel data. MIT press. 